\title{
'Visible Others': A Reading of the European Obsession with the Female Veil
}

\author{
Giorgia Baldi \\ School of Law, Birkbeck, University of London, United Kingdom
}

Copyright $(2017$ by authors, all rights reserved. Authors agree that this article remains permanently open access under the terms of the Creative Commons Attribution License 4.0 International License

\begin{abstract}
This article aims to analyse the current European obsession with the practice of veiling. What emerges from this analysis is that the regulation of clothes and images in the public sphere is an integral part of European history and emerges as a necessary act of sovereign power aimed at instituting a precise law and religious subject through regulation of the licit form of visibility in the public sphere. This act, reinforced by the promulgation of exceptional rules of law, is necessary to maintain the unity and homogeneity of European people, in the past as well as nowadays.
\end{abstract}

Keywords Headscarf Debate, Gender, Symbology of Clothes, Sovereignty, Power of Images, Secular/Religious Powers

\section{Introduction}

In recent years, the female headscarf has been at the centre of many polemical debates in Europe. Politicians, judges, journalists and columnists have even 'over-debated' the practice of veiling in the secular European public space, filling pages of journals and social media with stories of Muslim women who have been forbidden to work, to walk in a public place, to have appropriate education, and even to stand in a court room, because they are veiled. The obsession with women's veiling has led to a juridical regulation of women's body in many European countries. In 2004, France enacted the first bill to forbid 'religious symbols' in public schools while in 2010 it banned the full-face-veil from any public space [1]. In Germany, five German Landers, despite allowing the display of Christian symbols, adopted a law that banned Islamic symbols in public schools, while Austria and Belgium prohibited the full-face veil in public places, courts and schools [2]. At the same time, in the 'multicultural' UK, Shabina Begum, a young British student, was forbidden to attend school because she started to wear a jilbab instead of the uniform chosen by the school in consultation with three local imams [3]. The European Court of Human Rights' (ECHR) decisions, by applying a wide margin of appreciation, ${ }^{1}$ confirm those of European national courts. Although the veil has been worn for centuries by women in Arab-Islamic culture to communicate different meanings based on the specific context in which the practice is performed $[4,5]$, the female headscarf has come to be defined as a 'religious symbol incompatible with western secular values of gender equality' $[3,6,7,8]$. Those legal decisions support the view of many western scholars and commentators who see in the veil the symbol of something intrinsically 'other' while claiming the necessity of forbidding the veil in order to advance gender equality $[9,10$, $11,12]$ (as the veil is considered to be attire imposed on women that hides their bodies from the public space) and liberal/secular democratic principles (as it is considered to be a 'backward religious symbol' in contrast with secular/liberal values) $[13,14]$. Many of the debates over women's attire rely on a fundamental dichotomy between secular and religious, modernity and tradition, women's freedom and un-freedom: this binary opposition has become the main domain through which to read the current debate in Europe. In this context, (Muslim) women emerge as subjects needing to be 'saved' from a backward and chauvinist religion or as the enemy of western democratic values. Instead of analysing the matter of the veil through oppositional (western) categories, in this article I will address the dichotomy represented and fabricated over (Muslim) women's body through an anthropological, historical and political analysis of clothing regulation in Europe. As I shall point out, far from being a recent 'European obsession', the regulation of women's attire is an integral part of European history and emerges as a useful tool to create unity and homogeneity in a people: this 'necessary' act of sovereign power aims at creating a specific law and

1 The margin of appreciation plays an important role in remitting certain kinds of judgements to democratically elected officials who are said to know the particular context of their country better. It is usually employed by the ECHR when there is no formal European consensus on particular topics or where the issue is particularly controversial [50]. 
religious subject through the control of the visible in the public liberal/secular sphere.

I will critically address this argument through the analysis of two leading cases decided at the ECHR: Sahin v. Turkey [6], and Dahlab v. Switzerland [7]. Although diverse European national courts have disclosed different concepts of secularism, subject's autonomy and women's freedom in dealing with the matter, ${ }^{2}$ I consider these cases to exemplify the European obsession with (Muslim) women's clothes. Sahin, a young university student at Istanbul University, was denied access to a written examination because she was veiled. As no university in the country allowed the wearing of the veil, she was forced to move to Vienna University in order to complete her studies. After a long legal dispute in national courts, the case reached the ECHR and in 2005 the Grand Chamber decided that the university's refusal to allow her to wear a headscarf was justified under the exception made by Article 9 of the European Convention of Human Rights on freedom of thought and religion. ${ }^{3}$ The ECHR found that the ban on wearing the veil applied by the university was sought to 'preserve the secular nature of the institution concerned' [6] (para 116) and so was considered admissible. In the case, the Court defined the wearing of the veil as a symbol of affiliation with religious/political movements. However, the Court failed to prove the existence of extremist Islamist groups in the university and to explain the relation between the claimant and those groups. It also failed to give evidence that wearing a headscarf in a higher educational institution can 'pressure students who are not wearing the hijab' [6] (para 111). Dahlab v Switzerland [7] concerns a teacher in a primary school in Switzerland who, after a period of deep spiritual searching, converted to Islam and started to wear the hijab. Ms. Dahlab wore the veil for four years without telling students that she had converted to Islam [7] (456). The Director General of Public Education asked her to remove the veil: when Dahlab refused, alleging her right to wear the headscarf, she was dismissed. The ECHR,

2 In France, for instance, the banning of the veil has been framed in the name of state neutrality and public order (as wearing the headscarf has been considered a practice that challenges French social cohesion as well as secular principles) [51]. In Germany, eight Länder have passed a law prohibiting the wearing of the veil in public institutions in the name of 'religious pluralism' and for the 'protection of the Christian traditions' of the country [52]: thus, "while in France the notion of secularity has been interpreted in terms of a rupture from the Christian past, in Germany it has been regarded as implying a continuity of the Christian tradition" [53]. In the United Kingdom, where the government has taken a more flexible approach to cultural diversity, recent legal controversies in relation to the wearing of the veil at work and within educational institutions have re-opened the discussion about multiculturalism. Although national European courts have framed the issue of veiling differently, (Muslim) women's body remains at the centre of many polemical debates in Europe. 3 Article 9 'Freedom of thought, conscience and religion'. '9. 1 Everyone has the right to freedom of thought, conscience and religion; this right includes freedom to change his religion or belief and freedom, either alone or in community with others and in public or private, to manifest his religion or belief, in worship, teaching, practice and observance. 9.2 Freedom to manifest one's religion or beliefs shall be subject only to such limitations as are prescribed by law and are necessary in a democratic society in the interests of public safety, for the protection of public order, health or morals, or for the protection of the rights and freedoms of others.' in line with the Swiss Court, pointed out that Switzerland was pursuing a legitimate aim to ban the hijab in public schools in the name of gender equality (as the veil has been seen by the judges as a chauvinist practice imposed by the Koran) and state neutrality, considered an expression of the state's secularism. Ms. Dahlab's claim was dismissed and she was accused of proselytism although the Court could not prove that the claimant had pursued any proselytizing activities in the work place. In both cases, as well as in other European national juridical decisions over the female headscarf, the veil emerges as a 'religious symbol' in contrast with western liberal/democratic principles and veiled Muslim women as 'imaginary enemies' who threat western society.

But how can a simple article of clothing be understood to 'threaten' civil life? Why do clothes, particularly the female veil, have such an important place in western liberal democracy? Why, despite the wide plurality and performative outcomes of the practice, has the veil been defined as the 'symbol of' a monolithic and static belonging?

As Hansen argues, "because [clothing] both touches the body and faces outward others, dress has a dual quality... this two-sided quality invites us to explore both the individual and collective identities that the dressed body enables" [15] (p. 372). This is the why, in European history, clothes have always occupied a special place. In Medieval Europe, for instance, sumptuary laws ${ }^{4}$ were promulgated in periods of socio-political change in order to 'differentiate' between 'citizens' but also to 'homologate' as a means of strengthening a sense of national identity.

What is of particular interest in the study of clothing regulation is that although the promulgation of rules related to the individual's attire changed based on specific socio/historical periods, what remains constant in European history is an obsession with the regulation of women's clothes, especially women's veils. It is enough to look at how the matter of veiling has been historically negotiated to understand that the practice has been invested with different (ambiguous) meanings and values, and hence legally enforced or prohibited.

The history of European obsession with the juridical regulation of women's attire indicates that clothes have been intended as images, symbols and metaphors of a specific internal self, and, for this reason, they have the power to operate a visible differentiation, a boundary, a clear-cut dividing line, between citizens and foreigners and between the different classes of citizens [16]: through clothes, symbols and metaphors it is thus possible to conceptualize nationality, geography and gender, as it is through the visible that the public sphere comes to be shaped. I argue that since "forms of dress, as with forms of architecture, are not [only] mere metaphors for the power and authority of the political state [but] they instantiate the power and authority of the

4 "Sumptuary laws are attempts to regulate any kind of consumption, especially conspicuous consumption". [23] (p. 23) 
political state," [17] (p. xv) the sovereign power has always had a particular interest in regulating clothes in the public sphere. In essence, since clothes have been conceived as images, and images have the power to rhetorically construct (visible) forms of knowledge, the definition attached to a particular article of clothing emerges as an act of sovereign power aimed at maintaining the unity and homogeneity of a people $[18,19,20,21,22]$ : this, in turn, recalls the form of governmentality described by Schmitt [20, 21, 22]. In this view, the exclusion of many Muslim women from the public sphere is a necessary sovereign act to maintain unity and homogeneity in a fractured Europe. Through the juridical regulation of symbols and images in the public sphere, the sovereign not only gives to specific practices their proper place within the borders of the state but also, more importantly, it constitutes a specific law's subject obedient to a particular 'order of things' and faithful to an absolute and transcendent power. The 'politics of dress', then, which is an integral part of European history, not only reveals a certain anxiety in relation to clothing regulation, but also, more importantly, it is an example of the state's increasing intrusion into the private life of its citizens. This, in turn, reveals all the paradoxes of western/secular liberalism which creates a contradictory 'secular/liberal' subject: one who is free and, at the same time, compelled. In fact, if, on the one hand, the individual has rights (in the case, the right to express a religious belief by wearing a veil), then on the other, those rights can be threatened according to how the society and the nation-state want them to be regulated.

\section{Law, Power, and the 'Veiled Body'}

In the course of European history, rulers have spent considerable time and effort to promulgate laws related to the individual's apparel in the public sphere: in the Roman Empire, for instance, citizens sentenced to exile were forbidden to wear the toga, which was used to distinguish between the 'citizen' and the 'barbarian'. Similarly, the so called 'Sumptuary laws', promulgated throughout European history to restrict luxury and extravagance, emerge as an "intrinsic element in the formation of the modern legal [and social] order... [based on the] identification of 'imagined communities'... [as well as] moods of nation, class,... gender", and visible social hierarchies [16] (p. 708-9).

With the rise of Christianity in Europe, the place assigned to the body assumed a particular importance due to the "complex interconnection between flesh and cloth, between the naked and the clothed and their interplay, as with diaphanous materials that expose rather than conceal" [23] (p. 221): in fact, in teleological terms, clothes have been conceived through their symbolic meaning, as images, metaphors, of a specific order of things [16, 24]. Like every image, clothing has the potential to include and exclude and to delineate gendered territorial borders of an 'imagined community' $[24,25]$ as they express uniformity, hierarchy and regularity $[17 ; 26]$.

Tertullian's interest in apparel, for instance, reveals how regulation of the proper clothes to be exposed in the public sphere should mirror a divine transcendental order [27]. In his treatise, clothes emerge as a powerful image of an 'ordered society' through which the individual reads and interprets the external world, which, in turn, shapes her/his internal soul [16]: in other words, the external world should mirror the individual's internal 'being'. In fact, clothes do not only "make the human body visible" [17] (p. 1-2) as they are located at the border between the internal self and the external world, but also, more importantly, their symbolic meaning is understood as a semiotic code which shapes our and others' perceptions of the world [28].

Significantly, both Tertullian's treatise and the sumptuary laws promulgated in Medieval Europe focused mainly on the legal regulation of women's clothes: as dress is part of gender identity and represents an important mechanism for reproducing gender relations, "it follows that projects concerned with the regulation of dress must, whether intentionally or not, have an impact on the regulation of gender. It should be borne in mind that clothing works both ways; it is both a means of reading others and a means of displaying the identity of the wearer" [23] (p. 216). Thus, sumptuary law not only "manifests itself as a concern to establish some natural and stable connection between sex, gender and social role" [23] (p.217) but also, more importantly, it shows how women's body assumes an increasing importance in delineating matters of gender, territoriality and social status.

Hunt [23] suggests that anxiety toward women's attire and its legal regulation was strictly related to the controllability of women and emerges as a central part of the 'political economy of marriage' which is exemplified in the links between the dowry system and the promulgation of specific sumptuary laws. He notices that the rise of the nuclear family has been "associated with the rise of more public forms of control.... shifting sites of the private and public" [23] (p. 237). A particular interest in women's body is an important feature in Medieval Europe and it "stems from the notion that God's incarnation in the body of man was also his humiliation." The 'original sin', which manifests itself in the opposition between knowledge and faith, was transformed into 'sexual sin', "a sin that revolved around and was encapsulated in the body of women" [23] (p.222-3). As Burghartz [29] argues, "it becomes clear that the question of the right gender order, the right universally apparent social order and the godly moral order were tightly entangled with one another" (p.12). Interestingly, this entanglement has been represented by and fabricated over the women's veil, which in thirteenth century Europe acquires a growing symbolic importance in defining questions of women's modesty, gender difference, social status and social order [29].

Vecellio observes that although it was customary for Venetian women to reveal the face, in the 1550 s older 
women started to wear a black veil when going to church or during mourning, while in the 1590 s young unmarried girls started to use a white veil to cover the face and bosom. In adulthood, Venetian women wore the cappa, a black cloak that covered the face, while noble or upper-class women were accustomed to living secluded within domestic walls [29]. Likewise, drawing from the Lutheran reformer Paul Rebhun, who introduced women's compulsory veiling, the 1523 Luis Vives' manual for Christian women clearly takes the position that married women should be seen less in public as their devotion should be only for their husbands: he claims that in contrast to many Middle Eastern countries in which women observe the practice of veiling, European women "wore veils that allowed them to observe other people unimpeded, without themselves being visible. This needed to be stopped in the name of preventing immorality; women should cover their faces not with veils, but with decorum" [29] (p. 6).

Women's attire was not only related to their obedience to a specific gendered social order, but it also expressed the social status of male family members: for instance in 1474 a law on social status was promulgated in Bologna which stated that wives and daughters of knights should dress in gold, women related to bankers and notaries should wear only sleeves of gold, for those related to artisans the appropriate legal colour was crimson, while lower class women were allowed to dress only in crimson [23]. Thus, as Goodrich [16] argues,

\begin{abstract}
"a person's place in the imaginary order of nation or class was also a question of the order of images..., the regulation of dress, ornament, and food was linked to a theological and moral concern with the proper signs of identity and community. The legislation of the licit image of a person was linked indissolubly to the order of images and the role of symbols, of...the 'visible world' in public and private life" (p. 711-2).
\end{abstract}

If everybody had their proper place in a 'well-ordered society', women's place was mainly associated with respectability, modesty, austerity and morality. In Siena, for instance, sumptuary law prescribed a specific length for women's skirts (whereas only married women could wear long trains) while in Florence, in 1464, sumptuary laws were more concerned with women's décolletage; women were allowed to wear a décolletage three centimetres below the collarbone [23].

The medieval obsession with the legal regulation of women's attire was particularly emphatic during periods of political change: while the theological dispute between Luther and the Reformers focused mainly on the relationship between internal belief and external observance expressed in 'signs' [29], the 1075 Gregorian reforms expressed a particular anxiety over women's clothing regulation. Those anxieties toward women's body mirrored the wider juridical struggle between secular and religious authority over the jurisdiction of family law and moral offences. In fact, although there was a general consensus over the inferiority of women, secular and religious power had constructed different discourses in relation to the 'woman question': for the Church, women's identity should be related to morality because sings of luxury were seen as a sin, while within secular discourse, women's luxury was associated with the 'economic wrong of extravagance' [23]. This anxiety was symbolically expressed in the struggle over the female veil; on the one hand, the veil was seen by the Church as a sign of religious piety and sexual modesty while on the other, seculars saw it as alluring because it facilitated the concealment of identity: as a matter of fact, in Siena, officials were obliged to ask veiled women the name of their father or husband. What was at stake in this battle was the "degree of freedom veils allowed for assignations that breached patriarchal control and exhibited some degree of personal and sexual licence. This is borne out by the fact that prostitutes were frequently forbidden to wear the veil" [23] (p. 223). Besides, there was always strict cooperation between secular and religious authorities: "in Italy, in particular, there is evidence that the targeting of women points to the presence of the ecclesiastical hand behind sumptuary law during the Middle Ages. The morality of women was a central preoccupation and dress and ornamentation was the readily visible sign of immorality; the immoral character could be read from the immodest clothing" [23] (p.239-40). The distinction between the 'respectable' and the 'depraved' woman is mirrored in the many norms promulgated in that period: in 1351, the London Dress Ordinance imposed a strict dress code for prostitutes but highlighted that it had no value if the prostitute was of noble birth. In 1360, in Paris, a law forbade prostitutes to wear embroidered coverings, while in 1415 a statute was devoted exclusively to prostitutes' clothes in order to distinguish the 'depraved' from the 'respectable' woman and to avoid misunderstandings [23].

The obsession with the women's veil is also attested in the analysis of the many legal cases decided throughout Europe: in Basel in 1705, for instance, the Reformation Magistrates decided the case of seven women who entered a church without the Sturz (a traditional hood of stiff material). One of them claimed that she could not wear it due to her fragile constitution, two claimed ignorance of the normative relating to the veil, and the others justified it on the ground of poverty: the judges forgave the poor women and fined the others. A large fine was also imposed on Jacob Mechel when in 1709 his wife could not wear the Sturz because she was pregnant, and on many other husbands whose wives did not conform to the strict regulations [29].

Clothes regulations, however, were not only implemented to 'differentiate' between citizens, but also to create unity and homogeneity: in 1337 Edward III of England forbade the importation and wearing of foreign clothes, except for the royal family. The law stated that anyone acting or dressing as an 'Egyptian', a gypsy or a stranger was to be declared 
outlaw. Hence, if, on the one hand, clothes were regulated to establish class/group/gender differentiation, then on the other the 'English man' was to be recognized exactly by his clothes [30]. As, traditionally, external signs were considered the mark of internal states, "legal concern with dress was a concern both with the indigenous, with a vernacular civility free of the stranger...and with all other cults that were suggestive of traditions and forces extrinsic to the native soil" [30] (p. 88). Therefore, not only do clothes provide a sense of belonging but also, more importantly, they delineate the border between 'citizen' and 'foreigner': the first is included within the pale of the law, while the latter comes to be excluded by the law [16]. As identity is built through the negation of the 'image of the other', the rejection of 'foreign' clothes (with their specific shapes, cuts, and colours) is a precise political strategy to avoid 'foreign vices' and to create a sense of national belonging. Clothes, then, have been legally regulated not only to create the image of an 'ordered society', but also, more importantly, to build a fixed image of a territorial unified (imagined) community. In fact, as Anderson [25] argues, a nation is an 'imagined community', which implies a process of imaginistic individual identity formation whereas people recognize themselves as belonging to a particular group/community: this sense of belonging is negatively constructed through the differentiation and contraposition between the 'self' and the 'other', 'insider' and 'outsider', whereas symbols provide a clear-cut dividing line between different imaginaries, a useful tools to create unity and homogeneity through the figurative construction of an 'imagined' 'national' history, culture, and tradition. As individuals' perceptions are codified through images which work on an individual's pre-symbolic level, nationalism appropriates metaphors and symbols in the public sphere to create a specific paradigmatic and binary opposition between the self, citizen of the territorial 'nation-state', and the other, the 'outsider' [31].

The tension between religious and secular jurisdiction over women's body regulation expressed in the past came to an end with the fusion of secular and spiritual power [32,33] and the birth of nation states in Europe; women's body acquired a new meaning in the construction of the (national) 'imagined community'. In fact, within nationalist discourse women are seen as the biological/ethnic/cultural reproducer of the community; they symbolize 'national boundaries', the signifier of ethnic/cultural differences, the image of the 'other'. By metaphorically constructing the 'image of the nation' through women's body, the nation-state creates new gendered/national subjectivities which mirror and reproduce specific (national) cultural values: as Massad [34] observes, "metaphors of nationalist movements are not only metaphors. They also reflect the fundamental assumptions of nationalist thought, which establishes the future gender constitution and gender roles of nationalist agents" (p. 469).

The veil, which, in teleological terms, has been seen as a sign of women's modesty and legally imposed, ironically re-emerges in the eighteenth century as a 'sign of' women's fashion and in the nineteenth century as a fixed symbol of national belonging. In 1934, Turkey, for instance, banned the wearing of religious symbols in the public sphere, including the veil: the prohibition mirrored the attempt to create a strong, unified, and homogeneous nation-state through the juridical regulation of women's body in the public sphere [35].

But only since the colonial encounter has the veil come to symbolize an intrinsic difference between the 'east' and the 'west'. In fact, the veil has been constructed by colonizers as the symbol of the backwardness of Muslim culture, while "standing in the relation of antithesis to thesis... [the colonized have] reversed - but thereby also accepted - the terms set in the first place by the colonizers" [5] (p. 151) by elevating the veil as the symbol of their nationalist struggles. This is clear when studying the history of Algeria and Egypt, for instance, where banning the practice of veiling was one of the first legal reforms of the colonizers, but also in Turkey and Iran, where the newly created nation-state elevated veiling (along with 'unveiling', as in the case of Turkey) as a visible symbol of national belonging.

\section{The Symbology of the 'Otherness'}

The idea that dress can cause 'disruption', or that it can be intended as 'a threat to the values of a society', as in the current never-ending legal debate over the veil, shows that it is not the simple article of clothing but the symbology attributed to it that can threaten the status quo. While in the past the veil has assumed different meanings, nowadays it has become the symbol of women's oppression and of incompatible backward religious values, although in Muslim majority societies the veil carries different meanings $[4,5]$. The definition of veiling as a fixed 'religious symbol incompatible with democratic values of tolerance and gender equality' is an important feature in the European discourse over the veil. The power of symbols is well known in critical legal theory; through symbols and images, it is possible to understand what cannot be said directly as images remind us of ancestral myths still unattached to the symbols of institutional prose [30]. Since symbols have the power to create an illusion of presence and attachment to what is 'un-representable', then images are the point of fracture which defines the boundaries between the inside and outside of the law, as the 'veiled' woman, through her clothes, represents the boundaries of citizenship. In fact, as clothes have been regarded as a 'symbol', a 'visible image' of a different 'other', they have always been normatively regulated by the law through a sovereign act: garments operate a visible differentiation, a boundary, a clear-cut dividing line between citizens and foreigners and between the different classes of citizens.

The question that arises from this reading is who defines the meaning of a certain symbol? Who decides if the veil is a 'religious symbol' or not? If there is a wide literature about 
Islam and the use of the veil which points out the different uses and meanings of the hijab, why are states so concerned to regulate (Muslim) women's attire?

As Asad [36] points out, the banning of the veil can be understood as an exercise of sovereign power, as it is the sovereign that decides which symbol is to be regarded as 'religious' and, consequently, it acquires the power to shape the public sphere. Since the definition of 'religious symbols' becomes a juridical matter, the sovereign gains the teleological and transcendental power to impose those definitions on its subjects. The necessity of a sovereign power who decides upon exceptions is clear in the Stasi Commission's report ${ }^{5}$ which points out that the donning of the veil overloads teachers and public officers as they "are often left isolated, in a difficult environment to define which 'religious symbol' can be legitimate in a public school" [37]. It is also clear in the Sahin case [5], in which the ECHR, through a considerable emphasis on state neutrality and secular values, along with the distinction made by art. 9 between faith and its manifestation, ${ }^{6}$ widened the 'margin of appreciation', leaving considerable discretion to states to define what kind of religious manifestations are allowed in the secular public space. By stressing the principle of secularism, the Court not only limited Sahin's individual rights of freedom of religion, but it also "assumed the religious task of describing which Islamic duties are suitable to be performed at secular universities; practicing Muslim students in Turkish universities are free 'to manifest their religion in accordance with habitual forms of Muslim observance' (para 118 and 159)"'[38] (p. 273). ${ }^{7}$ Thus, if it is the sovereign power that decides exceptions and defines symbols, then "all modern concepts of the state are secularized theological concepts" [39] (p. 128) as the state assumes the teleological, transcendent and absolute power of defining images and metaphors in the public sphere: this is mirrored not only in past regulations over women's attire, but also, more importantly, in the recent ECHR legal decisions over the practice of veiling. In this sense,

\begin{abstract}
"[the] secular state today abides ... by the cuius regio eius religio principle (the religion of the ruler is the religion of his subjects), even though it disclaims any religious allegiance and governs a largely irreligious society...[in fact] it is not the commitment to... a particular religion that is most
\end{abstract}

5 The Stasi Commission was set up by the French Government in order to investigate the application of the principle of laicite in France.

6 In the ECHR's decisions, the term 'practice' in article 9 (1) "does not cover each act which is motivated or influenced by a religion or belief'. In fact, the manifestation should be one of the "normal and recognized manifestations" of religion or belief that "actually express the belief concerned" [54] (para 19, 20).

7 Clearly, the ECHR has identified 'religion' as a force that aspires to regulate human life and to subordinate secular to religious values: it relies on the assumption that religion should be relegated to a small private sphere in order to safeguard a wider secular public sphere. However, by defining religion as a simple private belief, not only has the Court circumscribed the role and place assigned to religion and religious practices but it has also imposed a narrow definition of religion on other cultures [55]. significant in this principle but the installation of a single absolute power - the sovereign state drawn from a single abstract source and facing a single political task: the worldly care of its population regardless of its beliefs. The state is now transcendent as well as a representative agent" [36] (p. 94).

In essence, as religion directs people to other loyalties and other 'worldly-powers', the state, the Leviathan, has to define its place in the worldly care of its population in order to assure the loyalty of the Christian/secular ${ }^{8}$ law's subject to a transcendental absolute power embodied in the sovereign who controls the public sphere through regulatory mechanisms that 'normalize' and 'naturalize' the private life of its subjects.

Therefore, if on the one hand liberal polity tries to operate a separation between private and public, spiritual and temporal, then on the other, the state takes the responsibility of creating Christian/secular citizens by regulating their private life, ethics, and sentiments through the control of symbols in the public sphere. By defining what the appropriate attire is for (Muslim) women, the sovereign state defines not only its subjects by 'clearing' the public sphere of 'intrusive symbols', but also the proper place for religion by bringing private sentiments into the public scrutiny of the secular polity. Thus, citizenship emerges as something that is constructed by an act of sovereignty, while the Christian/secular/liberal citizen becomes "a particular kind of contradictory individual - one who is morally sovereign and yet obedient to the laws of the secular republic, flexible and tolerant yet fiercely principled" [36] (p 104); a 'citizen' able to take part in the 'game of the sign' and thus show her loyalty to the absolute sovereign power. Through an exercise of sovereignty, the absolute power defines subjectivities by shaping the public space through the force of the law while defining the public limits of religious sentiments: paradoxically, the sovereign state "realizes its universal character through a particular (female Muslim) identity, that is, a particular psychological internality" [36] (p. 98).

But why does the sovereign state need an exercise of sovereignty to limit women's attire? Why, in the case of the 'Muslim' veil, was this act necessary to 'save' democratic values?

Based on Schmitt's analysis, what is important in a democracy is the 'unity' of a people, which is based on some sort of 'substantial homogeneity' and is symbolized in the figure of the sovereign. He argues that it is through the concept of 'substantial homogeneity' that it is possible to create a particular identity, able to clearly distinguish itself from other (foreign) identities [20]. This homogeneity, however, is based on an illusion, a 'fabrication', a 'false consciousness' constructed in order to maintain a

8 I have chosen to use this term because I see a continuation between Christianity and the secular $[32,33]$. 
homogeneous 'imagined' unity; as Anderson [25] argues, communities "are to be distinguished, not by their falsity/genuineness, but by the style in which they are imagined" (p. 6). Unity and homogeneity are established through a certain form of 'affective identity' which is translated into the 'affective' attachment to a unity represented by the sovereign. This 'affective attachment' is formed through the control and juridical regulation of symbols and metaphors in the public sphere [30]. As a matter of fact, historically, the appropriation of images and icons was compounded with the implementation of rules related to clothes as they have always represented cultural boundaries, accepted or rejected images of an (imaginary) community. Unity and identity, which coincide in Schmitt's analysis [21], become essential pillars of the political: unity is formed by an (imagined) common identity, while identity is shaped through the appropriation and legal regulation of what is visible in the public sphere. It is exactly in the name of a European (imagined) homogeneous identity, in the past as well as today, that the 'veiled woman' becomes the symbol of a fixed (Muslim) world which looks like the dictatorship of the Taliban in Afghanistan.

For Schmitt, to create a unified homogeneity, politics needs to create a contrast, a differentiation between homogeneity and plurality as pluralism threatens the sovereignty of the state and the existence of a (valuable) concept of politics; in fact, in pluralist theories the autonomy of the social system would not guarantee the unity of the system itself because "the state simply transforms itself into an association which competes with other associations" [27] (p. 44). Thus, plural theories threaten not only the unity and homogeneity of a people, but also the legitimacy and the sovereignty of the state, as the problem of conflicting loyalties arises. To maintain a homogeneous character, the sovereign needs citizens to be loyal to an absolute and transcendental power, the only one able to defend the 'being' of a people against 'intrusions'. Consequently, "conflict is possible as a structure of difference, and such a structure is only possible as a differentiation of unities ... [which makes] the origin of politics already political, already a battle about what constitutes a politically legitimate unity" [40] (p. 2).

Hence, what really threatens western societies is not a veiled woman, but the pluralism she represents. Not only is Islam a pluralistic religion, as it is open to interpretation and is praxiologically experienced differently in different contexts, but also the practice of veiling itself takes different shapes, colours and meanings which mirror different normative choices $[4,5]$. The battle between 'homogeneity' and 'plurality' is particularly clear in the Sahin case [6] in which the Court repeatedly emphasized the impossibility of reconciling Turkey's secular liberal and democratic values with extremist (Islamic) religious movements by referring to the Refah Party that, based on the Court's reasoning, attempts to introduce sharia law which 'would oblige individuals to obey static rules of law imposed by religious concerns'. However, the Court confused Refah
neo-Ottomanism, which calls for a plurality of legal systems based on personal status, with Islamist fundamentalists who call for the establishment of an Islamic empire where jurisdiction is territorial. Indeed, with regard to the distinction between personal/communitarian Islamic law and territorial/individualistic western law, it is clear that the ECHR's decision to dismantle Refah [41] was partly based on the ground that the party was planning to set up a plurality of legal systems. In the case, the Court's ignorance of the plurality of Islamic traditions regarding the veil was compounded by its rejection of a plurality of legal systems within the same territory qua political unit. It is clear, therefore, that in seeking to forcibly expose Turkish women's bodies to their natural rights the ECHR was also seeking to subjugate them under the logic of singular state sovereignty. ${ }^{9}$

If homogeneity and unity, and not plurality, are the bases of democracy, then how does politics make 'difference' possible? How can the 'right of belonging' be imaginatively constructed through the image, the 'symbol', of the 'other'?

For Schmitt [20], political communities are bounded by a fundamental dichotomy between 'friend' and 'enemy', 'insider' and 'outsider' which underlines every democracy: “'friend' and 'enemy', ultimately, have no content in themselves, they are oppositional positions capable of unifying the members of a group" (128). Thus, a strong and united community needs "first homogeneity and second [the] elimination or eradication" (p. 9) of the 'other': hence, the very idea of democracy is based on the concept of exclusion, of 'containing'/eliminating/hiding the differences and pluralities that ultimately threaten the monolithic character of liberal democracies by threatening their (imagined) homogeneity and unity. In fact, the people of a nation are bound by symbolic boundaries represented by the presence (as a negation) of the 'other' in the public sphere which challenges the national homogeneous identity of a people. Only through the identification and elimination of the 'enemy' are territorial and personal boundaries secured by an exercise of sovereignty in defence of democracy.

If, in the past, the 'enemy' was identified with the 'stranger', the 'outsider', the 'un-controllable', nowadays, Islam has become the 'other' and the hijab the symbol of 'otherness'. In fact, since the 1970s, sociologists have noticed that it is not any more the category of race, but that of 'immigrant', understood as "the result of their belonging to historical cultures" [42] (p. 22), which enables racist discourses: this, in turn, "entails a superimposition of different dimensions of 'otherness' that exacerbates issues of boundaries, accommodation and incorporation. The immigrant, the religious, the racial, and the socio-economic

9 If, as stated in previous legal cases decided at the ECHR, pluralism is an important feature in a democratic society [56; para $31 ; 57$, para 44$)$, how it is possible to justify the fact that when the individual works or studies in public places she has to comply with 'liberal' values? If wearing a hijab creates tensions and conflicts, as stated in the Strasbourg decision, then the parties should take measures to reconcile and not to prohibit group manifestations. 
dispriviledged 'other' all tend to coincide. Moreover, all those dimensions of 'otherness' now become superimposed upon Islam, so that Islam becomes utterly 'other"' [43] (p. 242). If Islam is the 'other', the veiled woman, who supposedly represents backward Islamic values incompatible with western democratic principles, is the symbol of this 'otherness': in this way, Muslim (veiled) women have been forcibly included in a symbolic and imaginary dichotomy between 'friend' and 'enemy', 'insider' and 'outsider' which underlies every democracy.

This is clear in the Dahlab case [7] in which the ECHR, instead of weighting the rights of Ms. Dahlab to wear the hijab with the rights and freedoms of others, presented an (imaginary) undefined 'other' in need of protection from the 'wrongdoing' of Ms. Dahlab. The Court presupposed that, because Ms. Dahlab was working with young children and the student-teacher relationship is a powerful one, her hijab could have 'proselytizing effects'. However, the Court did not find any coercive or proselytizing action carried out by the applicant to induce students to behave or believe in the same way she did. It is not clear what kind of 'bad influence' or 'proselytizing effects' Ms. Dahlab was exercising on 'vulnerable children' since she did not even tell them that she had converted to Islam. ${ }^{10}$ In the Sahin case [6] the claimant has been presented as part of a dangerous religious radicalism from which the society must be defended. In the case, by focusing on the history of Turkey and the (supposed) existence of extremist religious movements attempting to overthrow the secular state through the reference to the Refah case [41], the ECHR made a mistake: it "substituted Turkey for the University of Istanbul and Islam for the headscarf" [38] (p. 279). It also failed to give evidence that wearing a headscarf in a higher educational institution can "pressure students who are not wearing the hijab" [38] (p. 279). As Sahin was a university student, and not a teacher in a primary school like Dahlab, the argument that veiling can be seen as a tool for proselytism is extremely weak.

Those legal decisions illustrate how the concept of 'radical otherness' is established through the boundary expressed by the law. To maintain democracy, as Schmitt observes, the boundary between 'insider' and 'outsider' becomes crucial and the identification and expulsion of the 'other' from the public sphere necessary. As Fadil [44] puts it in relation to the banning of the full-face veil in Belgium, "the exclusion of

10 The dichotomy between 'friend' and 'enemy' is clear in Germany, in which five German Landers have allowed the display of Christian symbols, but not Islamic ones and in the Begum case [3] in which a young British student in the UK was forbidden to attend her school because she started to wear a jilbab and not a shalwar kameeze, considered the most appropriate uniform for Muslim women by three local imams. This is particularly indicative of western binary perceptions of Muslims as the court implied the existence of two kinds of Muslim: those 'accommodated' in liberal/democratic societies, and Islamic fundamentalists from whom western democracy has to be defended [18]. This dichotomy is also clear in a passage of the French resolution over the practice of veiling which stresses the "power and the duty we have to oppose ideologies and ways of thinking [symbolized by the full-face veil] that one can only qualify as 'barbarian', in the sense that they deny the idea of progress, of civilization, of democracy, of sex-based equality...it's our value system which is at issue...this is our Republic being tested in this way."[37]. face-veiled women as 'abject other' enables a minimal sense of 'we-ness' in the fractured Belgium but also in other Western-European countries where citizenship is increasingly cast in cultural terms" (p. 88). The history of clothing regulation as well as the recent legal decisions over the practice of veiling highlight that it is exactly through boundaries, expressed symbolically by the veil, that the (fixed) identity of the 'self' and the 'other' emerges: the necessary exercise of sovereignty operated by the authority to bind women to a fixed subjectivity can be seen as an effort to maintain differences and, thus, a homogeneous and unified nation-state: "If terrorism or Islamic fundamentalism did not exist, they would have been invented" [45] (p. 50).

\section{Conclusions}

The obsession with the regulation of clothes, in particular the female veil, is not a new phenomenon in Europe; rather it is an integral part of western legal history through which it is also possible to read current European legal decisions over the practice of veiling. In fact, it is exactly through the study of clothing regulation that it is possible to understand the power of dress in shaping the public sphere: as I have argued, since clothes are located at the margin of the body, they symbolize the boundary between the self and the external world $[15,16,17]$. Through clothes it is thus possible to conceptualize nationality, geography and gender as a rhetorical form of the visible which "make[s] the world known to different individuals, who thereby engage, on the basis of such knowledge, in the ongoing refashioning of life in the public spaces" [46] (p. 120). In fact, the visible, unlike the 'visual' which is a simple 'representation', depends upon a symbolic order which emerges as "a rhetorical form that produces effects merely through what is rendered as 'self-evident' or 'natural'" [46] (p. 133). It is therefore clear that the legal regulation of clothes does not aim to 'cover' or 'un-cover', but to 'order' and control the public sphere to rhetorically construct meanings and subjectivities.

It is exactly the construction of different meanings attached to a particular article of clothing, such as the veil, that is at stake in past and present regulation of women's attire: in European history, the female veil has been associated with women's modesty in medieval times and women's fashion in the eighteenth century, and it re-emerges in the colonial period as the 'Muslim veil'; the symbol of the intrinsic and irreconcilable difference between west and east. Ironically, however, while the veil has always been regulated in western countries (whether by religious or secular power), in the 'east' the practice, which assumes different meanings based on specific cultural and historical contexts and was part of the Arab-Islamic tradition for centuries, started to be legally regulated only with the birth of nation states, apart from very short periods during the Abbasid era [5].

As, historically, western semiotic as well as nationalist ideology has attached specific meanings to the external 
'sign', the plurality of performative practices expressed in the veil in Muslim majority societies has been reduced by the ECHR to a monolithic symbol of an intrinsic dichotomy between a 'secular' and 'tolerant' west and a 'religious' and 'backward' east; after all, the history of women's veil regulation in Europe reveals that even a simple piece of cloth such as the veil can be invested and saturated with meanings established by a sovereign authority through the force of the rules of law.

Since the inscription of women's bodies into the homogeneity of western democracy has been set by the law, Muslim women have been unveiled to be re-veiled with the mask of the unified Christian/secular law's subject which emerges with her 'new clothes' as the image, the mirror, of a precise legal order, of law's appearance in the social realm: "the social body, the icon and mode of civility, included and annexed the subject ... it was the logic of the mirror, of mimetic duplication, of the mask or image, which is to say, of the father in the son" [30] (p. 89-90). In fact, if metaphors produce the necessary emotional attachment to legal obedience and political love, then the visible has to mirror a specific order of power and imagination and the legal subject should mirror a legitimate order of thought [30]: as Deleuze [47] points out, "the mask is the true subject of repetition. Such is the case because the nature of repetition differs from that of representation, because the repeated cannot be represented, but must always be signified, while masking at the same time that it signifies" (p. 29).

Therefore, the legal subject comes to be formed and, at the same time, subjugated, by and through a specific form of visibility. In essence, the regulation of images and clothes in the public sphere emerges as the regulation of the 'licit' form of visibility and its proper reference in order to forge and create a specific law's subject: "the discourse against rhetoric, against images, and against women... are discourses of the foundation of law in the definition and capture of subjectivity" [30] (p. x). Thus, by regulating clothes, law allows a double movement: on the one hand, by determining form and languages in advance, the rules of law form a specific Christian/liberal/secular citizen and its being, its desires, while on the other, it takes significant steps in limiting the personal freedom of women by representing the constructed desires of a majority of European people in search of an abstract, unified and universal identity which is formed through the regulation of images in the public sphere. In the specific case, two women have been removed from the public space just because their image did not conform to the western/secular conception of 'liberated woman'. This not only reveals that in liberalism the individual emerges as an abstract entity who, while enjoying the allowed freedoms, is also subjected to the state's rules, but it also unmasks the intrinsic paradoxes of positive and Human Rights law. In fact, if on the one hand the western secular/liberal subject of law enjoys a freedom guaranteed by the state, then on the other $\mathrm{s} / \mathrm{he}$ must to be subject to state power in order for her/his freedom to be protected. The paradox of Human Rights law is also revealed by the fact that although the individual has 'equal rights', those rights can be regulated to a greater or lesser degree depending on how abstractly or concretely the individual is perceived to be using these rights. This is particularly clear in the comparison between Dahlab [7] and the Kokkinakis case [56] decided at the ECHR. Kokkinakis v Greece involved two Jehovah's Witnesses who were charged with the criminal offence of proselytizing after knocking on the door of diverse Greek Orthodox priests in order to try to convince them of the truth of their religion in a country where it is illegal. ${ }^{11}$ Oddly, for the ECHR, Ms. Dahlab's clothing represented a greater threat to liberty than Mr. Kokkinakis's attempt to proselytize: in fact, the former was considered by the ECHR as a form of proselytism whiles the latter was not. ${ }^{12}$ While, for the Court, it was not necessary to regulate proselytizing actions such as that committed by Kokkinakis in a country where this action was considered illegal by the domestic Court, in Switzerland, removing a woman from the public space because she has started to wear the veil has been presented by the ECHR as a necessity to save the principle of 'state neutrality'.

Therefore, although Human Rights law claims to redeem humanity through the force of the law, it actually acts to eradicate cultural differences in the name of a fixed and monolithic secular/liberal law's subject: one who is free and, at the same time, compelled. Likewise, on the one hand liberalism justifies itself by claiming a separation between the spiritual and the temporal, the private and the public, while on the other, the private life of the individual has become extremely regulated. In the case, in order to 'save' western secular values, some personal rights of Muslim women and their possibility of agency have to be limited.

The history of clothes' regulation in Europe shows that the law demonstrates anxiety "when individuals attempt to perform their own public face, through personal modes of dress and undress, in the liminal space of dress that the law takes to be a locus of its own dominion ... When we choose to dress ourselves publicly in a particular way, we are exercising a form of self-government. We are taking control of our little state" [17] (p. 123). In the case, by wearing (or removing) a veil, the law's subject is appropriating her right to regulate her own relation between her private life and the civil/public sphere.

Therefore what is at stake in the legal regulation of women's attire is the increasing penetration of the state (be it 'secular' or 'religious') in the individual's private life; in essence, the legal regulation of clothes mirrors the expansion of the regia potestas over the subject's soul whereas "public reason defines a private being which only has a legitimate existence within the public sphere of its representation" [30]

11 In Greece proselytism is forbidden by constitution. For this reason, $\mathrm{Mr}$ Kokkinakis was judged guilty by the Greek Court. See Art. 13. 2 of the Greek constitution [59].

12 The Court held that the conviction of the Greek national court against $\mathrm{Mr}$. Kokkinakis was a breach of article 9 of the ECHR because the simple attempt to convince others of a religious belief cannot be considered a breach of freedom of religion. Kokkinakis [56] (414). 
(p. 92). This intrusion of the state in the private life of the individual "concerns the routine inscription and registration of the most private and most incommunicable element of subjectivity - the biopolitical life of the body" [48] (p. 2012 ) and emerges as a necessary exercise of sovereignty aimed at preserving political unity and homogeneity. In fact, if, as Schmitt argues, unity and homogeneity are formed by the creation of a fundamental dichotomy between 'friend' and 'enemy', 'insider' and 'outsider', then, as a prince and supreme legislator, the sovereign creates a (necessary) exception, a 'disturbance', a dichotomy symbolized nowadays by the (Muslim) veil, which must be rendered invisible by 'exceptional' rules of law.

This (imagined) dichotomy, symbolized in the past as well as nowadays by women's bodies, is mirrored in the current ECHR legal decisions over the practice of veiling which rely on a fixed binary opposition between a 'tolerant' Christian/secular thought, presented as a central value in western civilization, and a 'un-democratic' Islamic thought, presented as a threat to western democracy. It is through this dichotomy that homogeneity is easily attained "when the basic difficulty is emphatically ignored and when, for formal reasons, everything that contradicts the system is excluded as impure"[21] (p. 21). Those decisions reveal that symbols are constructed in order to create homogeneity in contraposition with an imaginary 'enemy', which is, at least, the 'plurality of the other': "both the imposition to learn 'under the cross' and that to learn bareheaded indicate the existence of a homogeneous collective identity and of outsiders, who have the choice between accepting to share, even symbolically, the values of the majority, or to be excluded from the public sphere"[18] (p.2666). Thus, as Gunn points out [49], "despite the popular beliefs that laïcité and religious freedom are founding principles that unite the citizens of their respective countries, they actually operate in ways that are more akin to founding myths...in current controversies involving religion and the state, where the doctrines are cited for the ostensible purpose of resolving conflicts, they continue to be applied in ways that divide citizens on the basis of their beliefs and that belittle those whose beliefs do not conform to popular preferences" (p. 422) In essence, secularism and western positive law act to eradicate differences and to protect a 'secular citizen' through the control of women's body. This, in turn, reveals western incapacity to think juridical plurality.

\section{REFERENCES}

[1] Commission De Réflexion sur l'application du principe de laïcité dans la République, Rapport au Président de La République (2003)

http://lesrapports.ladocumentationfrancaise.fr/BRP/03400072 5/0000.pdf, accessed 15 October 2014, italics added

[2] The Islamic Veil across Europe (2017) BBC, available at http://www.bbc.com/news/world-europe-13038095
[3] R. (on the application of Begum) v Denbigh High School Governors, [2004] A.C.D. 66 Queen's Bench Division (Administrative Court), see also $\mathrm{R}$ (on the application of Begum (by her litigation friend, Rahman)) (Respondent) $\mathrm{v}$ Head teacher and Governors of Denbigh High School (Appellant), [2006] UKHL 15, House of Lords, Session 2005-06, (on appeal from [2005] EWCA Civ 199)

[4] Abu-Lughod L, Veiled Sentiments: Updated with a New Preface: Honor and Poetry in a Bedouin Society (2nd Revised edition, University of California Press 2000)

[5] Ahmed L, Women and Gender in Islam: Historical Roots of a Modern Debate (Yale University Press, 1992)

[6] Sahin v. Turkey, (2005) ECHR Grand Chamber judgment. (Application No. 44774/98)

[7] Dahlav V Switzerland (Application 42393/98) ECHR, 2001

[8] Karaduman v Turkey, (Application No. 16278/90), ECHR, Decision of $3^{\text {rd }}$ May 1993

[9] Chouki El Hamel, Muslim Diaspora in Western Europe: The Islamic Headscarf (Hijab), the Media and Muslims' Integration in France, 6 CITIZENSHIP STUD. 293, 303 (2002).

[10] Edien Bartels, "Wearing a Headscarf Is My Personal Choice" (Jasmina, 16 years), 16, ISLAM \& CHRISTIAN-MUSLIM REL. $15,17(2005)$.

[11] Sarah Eltantawi, Yes or No to Hijab: Not for Men to Decide, MUSLIM WAKEUP!, Feb. 12, 2004,

http://www.muslimwakeup.com/main/archives/2004/02/yes_o r_no_to_hi.php.

[12] Mernissi, Fatima. Women and Islam: An historical and theological inquiry. South Asia Books, 1991.

[13] Marie Brenner, Daughter of France, Daughters of Allah, VANITY FAIR, Apr. 2004.

[14] Mezri Haddad, Voile islamique-la loi au-dessus de la foi, $L E$ FIGARO (Fr.), Oct. 14, 2003.

[15] Hansen, Karen Tranberg. 2004. 'The World in Dress: Anthropological Perspectives on Clothing, Fashion, and Culture'. Annual Review of Anthropology, 369-92.

[16] Goodrich, Peter. 1998. 'Signs Taken for Wonders: Community, Identity, and A History of Sumptuary Law'. Law \& Social Inquiry 23 (3): 707-28.

[17] Watt, Gary. 2013. Dress, Law and Naked Truth: A Cultural Study of Fashion and Form. A\&amp; C Black

[18] Mancini, Susanna. 2008. 'Power of Symbols and Symbols as Power: Secularism and Religion as Guarantors of Cultural Convergence', Cardozo L. Rev. 30: 2629.

[19] Mancini Susanna. 2014. 'The Tempting of Europe, the Political Seduction of the Cross: A Schmittian Reading of Christianity and Islam in European Constitutionalism'. Oxford: Oxford University Press.

[20] Schmitt, Carl. 1976. The Concept of the Political. Rutgers University Press

[21] Schmitt, Carl. 1985. Political Theology: Four Chapters on the Concept of Sovereignty /. Studies in Contemporary German Social Thought. MIT Press. 
[22] Schmitt, Carl. 2008. Constitutional Theory/. Duke University Press.

[23] Hunt, Alan. 1996. Governance of the Consuming Passions: A History of Sumptuary Law /. Language, Discourse, Society. Macmillan Press.

[24] Hammond, Henry. 1646. Of Idolatry. Henry Hall, Printer to the Universitie

[25] Anderson, Benedict. 1991. Imagined Communities: Reflections on the Origin and Spread of Nationalism. Verso

[26] Blake, C. Fred. 1994. 'Foot-Binding in Neo-Confucian China and the Appropriation of Female Labor'. Signs, 676-712

[27] Dunn, Geoffrey D. 2013. 'Tertullian'. In ‘The Encyclopedia of Ancient History’. John Wiley \& Sons, Inc.

[28] Barthes, Roland. 2006. The Language of Fashion /. English ed. Berg.

[29] Burghartz, Susanna. 2015. 'Covered Women? Veiling in Early Modern Europe'. History Workshop Journal, 80:1-32. Oxford Univ Press.

[30] Goodrich, Peter. 1995. Oedipus Lex: Psychoanalysis, History, Law /. Philosophy, Social Theory, and the Rule of Law. University of California Press.

[31] Landes, Joan B. 2003. Visualizing the Nation: Gender, Representation, and Revolution in Eighteenth-Century France. Cornell University Press.

[32] Kantorowicz, Ernst Hartwig. 1957. The King's Two Bodies: A Study in Mediaeval Political Theology /. Princeton University Press.

[33] Diamantides, Marinos. 2006. 'Toward a Western-Islamic Conception of Legalism'. in Law, Text, Terror: Essays for Pierre Legendre, Peter Goodrich, Lior Barshack, Anton Schutz (eds). Oxon: Glass House Press.

[34] Massad, Joseph. 1995. 'Conceiving the Masculine: Gender and Palestinian Nationalism'. Middle East Journal 49 (3): $467-83$

[35] Quataert, Donald. 1997. 'Clothing Laws, State, and Society in the Ottoman Empire, 1720-1829'. International Journal of Middle East Studies 29 (03): 403-25.

[36] Asad, Talal. 2006. 'French Secularism and the "Islamic Veil Affair"'. Hedgehog Review 8 (1/2): 93

[37] Commission De Réflexion sur l'application du principe de laïcité dans la République, Rapport au Président de La République (2003) http://lesrapports.ladocumentationfrancaise.fr/BRP/0340007 25/0000.pdf, accessed 15 October 2014.

[38] Altiparmak Karem and Karahanogullari Onur. 2006. 'European Court of Human Rights: After Sahin: The Debate on Headscarves Is Not Over, Leyla Sahin v. Turkey, Grand Chamber Judgment of 10 November 2005, Application No. 44774/98', 2 European Constitutional Law Review 268, 279

[39] Kelly, Duncan. 2004. 'Carl Schmitt's Political Theory of Representation'. Journal of the History of Ideas 65 (1): 11334.
[40] Rasch, William. 2000. 'Conflict as a Vocation Carl Schmitt and the Possibility of Politics'. Theory, Culture \& Society 17 (6): $1-32$

[41] Refah Partisi (The Welfare Party) and others v. Turkey, Application nos. 41340/98, 42342/98 and 41344/98 (ECHR $31^{\text {st }}$ July 2001)

[42] Balibar, Etienne, and Immanuel Maurice Wallerstein. 1991. Race, Nation, Class: Ambiguous Identities. Verso.

[43] Casanova, José. 2006. 'The Long, Difficult, and Tortuous Journey of Turkey into Europe and the Dilemmas of European Civilization'. Constellations 13 (2): 234-47.

[44] Fadil, Nadia. 2011. 'Not-/unveiling as an Ethical Practice'. Feminist Review 98 (1): 83-109

[45] Zhang, Xudong. 2004. 'Multiplicity or Homogeneity? The Cultural-Political Paradox of the Age of Globalization'. Cultural Critique 58 (1): 30-55.

[46] Vivian, Bradford. 1999. 'The Veil and the Visible'. Western Journal of Communication 63 (2): 115-39.

[47] Deleuze, Gilles. 2000. Différence et Répétition. Presses Universitaires de France - PUF.

[48] Agamben, Giorgio, and Stuart J. Murray. 2008. 'No to Biopolitical Tattooing'. Communication and Critical/cultural Studies 5 (2): 201-2.

[49] Gunn, T Jeremy. 2004. 'Religious Freedom and Laïcité: A Comparison of the United States and France' BYU L. Rev. 419, 422.

[50] Arai-Takahashi Y, and Arai Y. 2002. The Margin of Appreciation Doctrine and the Principle of Proportionality in the Jurisprudence of the ECHR (Intersentia $n v$ )

[51] Brems, Eva. 2006. ‘Above Children's Heads: The Headscarf Controversy in European Schools from the Perspective of Children's Rights'. INTERNATIONAL JOURNAL OF CHILDRENS RIGHTS 14 (2): 119.

[52] Schiffauer. W. 2006. 'Enemies within the Gates. The Debate about the Citizenship of Muslims in Germany'. in Multiculturalism, Muslims and Citizenship, Tariq Modood, Anna Triandafyllidou, Ricard Zapata-Barrero (eds), 94-116. London, UK: Routledge.

[53] Amir-Moazami, Schirin. 2005. 'Muslim Challenges to the Secular Consensus: A German Case Study'. Journal of Contemporary European Studies 13 (3): 267-286

[54] Arrowsmith v the United Kingdom (App. N. 7050/75 ) (1978) 19 Eur Comm HR 5, 19, 20.

[55] Nielsen, Jørgen. 1999. Towards a European Islam (Palgrave Macmillan UK)

[56] Kokkinakis v Greece (Application 14307/88) ECHR 25 May 1993 A. No. 260

[57] Manoussakis and Others v. Greece, Application No. 18748/91ECHR 26 Sept. 1996, IV RJD

[58] 'Constitution of Greece' $<$ http://www.hri.org/docs/syntagma/artcl25.html $>$ accessed 4 May 2016. 